long-distance trading, expeditions, networks, relay trading, and transit markets; conditions for the emergence of specialized trading groups, their distinctive organization and ideology and their relations with host communities.

The Adaptation of African Economies and Trading to Changes in the nineteenth-century European Trade on the Coast: economic and social consequences of the growth and changing character of overseas trade.

The Impact of Modern Capitalism on African Trade: the position of African traders in the development of modern commerce, problems of African capital formation, responses to the development of urban consumer markets.

Comparative review of the Spheres and Categories of African Trade: the influence of geographical, socio-cultural, and political factors; the classification and elements of trade; reconsideration of concepts and theories.

The work of the seminar is being prepared for publication in a book which will include an introductory essay by the chairman which will review the discussions and the preparatory papers.

\title{
Budapest Conference on Problems of Economic Development in Africa
}

A conference on 'The Implementation Problems of Economic Development Plans and Government Decisions in the Countries of Black Africa' was held in Budapest from 3 to 9 March 1969, and was attended by participants from the U.S.S.R., German Democratic Republic, Poland, Romania, Czechoslovakia, Mongolia, India, and Hungary. Further information may be obtained from: Mr. Paul Páricsy, Centre for Afro-Asian Research of the Hungarian Academy of Sciences, Budapest XII, Kallo esperes I s, Hungary.

\section{Société Africaine de Culture: Symposium at Porto-Novo}

A symposium on traditional African religions as a source of cultural values, organized by the government of Dahomey and the Société Africaine de Culture, with the co-operation of Unesco, will be held at Porto-Novo from I 6 to 22 August 1970. A number of African and non-African specialists are being invited to contribute papers relating to institutions and legal systems, customs, technology, art, and cosmology. The influence of Islam and Christianity in Africa will be considered in the context of traditional African religions. There will also be papers on the Antilles and the Americas. Further information about the Symposium may be obtained from the Secretary-General, Société Africaine de Culture, 'Présence Africaine ', 42 rue de Descartes, Paris 5 ${ }^{\text {e }}$ or, M. le Secrétaire-Rapporteur, Comité National de Préparation du Colloque sur les Religions Traditionnelles Africaines, Commission Nationale pour l'Unesco, Ministère de l'Education Nationale, Porto-Novo, Dahomey.

\section{African Folklore Conference: Bloomington, Indiana, July 1970}

The Folklore Institute of Indiana University will sponsor an African Folklore Conference, to be held in Bloomington, Indiana, on 16,17 , and I 8 July 1970 . It will continue the series of special summer programmes in Folklore held at Indiana University every four years since I942. Scholars from Africa, Europe, and the United States will discuss the genres of African folklore, oral tradition as literary art, the influence of African folklore on modern African literature, relationships between African folklore and American Negro lore, African folklore as a source for the historian, and teaching materials for courses in African oral traditions. Further information and reservations may be obtained from the Director of the Folklore Institute, 7 r $_{4}$ East 8th Street, Indiana University, Bloomington, Indiana $4740 \mathrm{or}$. 